\title{
List of interviews and correspondence
}

Borčič, Barbara. E-mail correspondence with the author, February 17, 2021.

Cibic, Jasmina. Conversation with the author, March 3, 2019.

Čufer, Eda. Conversation with the author, August 7, 2019; e-mail correspondence with the author, August 21 and November 4, 2019.

Čupić, Rada. E-mail correspondence with the author, February 14-18, 2021.

Delimar, Vlasta. Conversation with the author, June 12, 2019.

Dimitrijević, Olga. Conversation with the author, December 25, 2019.

Dobnikar, Mojca. E-mail correspondence with the author, October 15, 2019.

Đurić, Dubravka and Miško Šuvaković. E-mail correspondence with the author, January 27, 2021.

Galántai, György. Conversation with the author, December 21, 2011.

Goldstein, Joshua S. E-mail correspondence with the author, February 16-19, 2021.

Gržinić, Marina. Conversation with the author, August 10, 2019; e-mail correspondence with the author, September 21 and 22, 2019.

Iveković, Sanja. Conversation with the author, June 13, 2019.

Jakšić, Jasna. Conversation with the author, June 11, 2019.

Janečić, Helena. Conversation with the author, July 30, 2020.

Jelača, Dijana. E-mail correspondence with the author, August 16, 2019.

Kamerić, Šejla. Conversation with the author, January 29, 2021.

Kesić, Saša. Conversation with the author, August 11, 2018.

Ladik, Katalin. Conversation with the author, January 8, 2012.

Miljković, Boris. E-mail correspondence with the author, July 14, 2020.

Mlađenović, Lepa. Conversation with the author, December 25, 2019.

Mohar, Miran. E-mail correspondence with the author, July 20, 2020.

Murkus, Amal. Conversation with the author, February 23, 2021.

Novak, Ivan. E-mail correspondence with the author, July 3 and 7, 2020.

Ostojić, Tanja. Conversation with the author, November 13, 2019.

Pavlović, Vesna. E-mail correspondence with the author, August 22, 2020.

Raščić, Lala. Conversation with the author, September 5, 2019.

Selman, Selma. Conversation with the author, August 5, 2019. 
Tijardović, Jasna. Conversation with the author, October 13, 2019.

Tomić, Biljana. Conversation with the author, August 4, 2011.

Tratnik, Suzana. Online chat correspondence with the author, August 9, 2019. Tumbas, Eržebet. Conversation with the author, June 15, 2018.

Videkanić, Bojana. E-mail correspondence with the author, March 8, 2020.

Vogelnik, Borut. E-mail correspondence with the author, August 9, 2020.

Vukadinović, Dragica. E-mail correspondence with the author, July 12, 2019.

Zajović, Staša. Conversation with the author, December 25, 2019.

Žilnik, Želimir. Conversation with the author, August 13, 2019. 